\title{
The Crime of Genocide in Ethiopian Criminal Law: Analysis of Its Definition and Scope in Light of International Criminal Law
}

\author{
Diriba Adugna Tulu \\ Public Prosecutor at Attorney General Office Of Oromia Regional State, Ethiopia
}

\begin{abstract}
The purpose of this paper is to analysis the definition and scope of the crime of Genocide under Ethiopian criminal law in light of GC and ICC Statute. The paper is normative legal research by using statute, case, and conceptual approaches. The legal material analysis technique is done by the qualitative method of interpretation. The result showed that the definition of the crime of genocide and scope of possible victims provided under Ethiopian criminal law is wider than what is stated under the international criminal law.
\end{abstract}

Keywords: Genocide Convention, ICC Statute, Ethiopian Penal Code, Penal Code, FDRE Criminal code.

DOI: $10.7176 / \mathrm{IAGS} / 82-02$

Publication date:May $31^{\text {st }} 2020$

\section{Acronyms}

FDRE - Federal Democratic Republic of Ethiopia

GA - General Assembly ICTY- International Criminal Tribunal for the Former Yugoslavia

GC - Genocide Convention ILC - International Law Commission

ICC - International Criminal Court SPO - Special Prosecutor Office

ICTR- International Criminal Tribunal for Rwanda UN- United Nations

\section{Introduction}

\subsection{Background of the Study}

Genocide as a legal term is a recent historical development. Following the atrocities of the Holocaust, the international legal community was left with the responsibility of defining the unprecedented acts that had been committed. Winston Churchill infamously referred to the acts committed by Nazi German's as "a crime without a name." Though the term became popularized at the time, those prosecuted for crime during the Second World War were prosecuted for "crimes against humanity," rather than "genocide." In 1945, the international community began the process of institutionalizing the definition of genocide. The UN Economic, and Social Council, at the request of the UN GA, produced the convention on the prevention and Punishment of the crime of Genocide. The convention was ratified in 1951 and has since remained unaltered. ${ }^{2}$

The newly established crime of genocide was then repeatedly the subject of discussions within the UN; special mention is due to the reports submitted by Ruhashyankiko ${ }^{3}$ and Whitaker ${ }^{4}$ and to the work undertaken by the ILC resulting in Article 17 of the 1996 Draft Code of crimes against Peace and Security of Mankind. ${ }^{5}$ Article II of the GC was incorporated tel quell into the statutes of the ICTY and the ICTR. On 2 September 1998, the ICTR, in Prosecutor v. Akayesu, rendered the first international conviction ever for genocide and until now the ICTR remains the international criminal jurisdiction with the most elaborate case law on the crime of genocide. Again without any change, Article II of the GC was transposed into Article 6 of the ICC Statute. The elements of crime of the $\mathrm{ICC}^{6}$ contain a number of important indications as to the more specific content of the crime.

Ethiopia, as a signatory to the GC recognized that at all periods of history genocide has inflicted great losses on humanity; and confirmed that genocide is a crime under international criminal law. ${ }^{7}$ Therefore, Ethiopia is bound by to adhere to its provisions. In order to give effect to its international obligation, Ethiopia, expressly criminalized genocide under its 1957 Penal Code. ${ }^{8}$ The Ethiopian 1957 Penal Code at the time was progressive in its inclusion of the prevailing international criminal law governing genocide.

\footnotetext{
Quigley, John B. (2006). "The Genocide Convention: An International Law Analysis” (Aldershot, England: Ashgate Pub), p. 4

Jorgensen, (2001). "The Definition of Genocide: Joining the Dots in Light of the Recent Practice" International Criminal Law Review 1, no. 3-4: $285-313$, p.5.

${ }^{3}$ Study on the question of the prevention and punishment of the crime of genocide, U.N.Doc. E/CN.4/Sub.2/416, 4 July 1973.

4 Revised and updated report on the question of the prevention and punishment of the crime of genocide, U.N. Doc.E/CN.4/Sub.2/1985/6,2 July 1985 .

5 Ibid.

6 ICC-ASP $/ 1 / 3$

${ }^{7}$ Ethiopia ratified the Convention on 1 July 1949,

http://treaties.un.org/pages/ViewDetails.aspx?src=TREATY\&mtdsg no=IV1\&chapter=4\&lang=en, accessed 17 April, 2020.

8 The Penal Code of the Empire of Ethiopia, Proclamation No. 158/1957, promulgated on 23 July 1957, Art 281.
} 


\subsection{Statement of the Problem}

The crime of genocide has been defined under international instruments. The GC contains the definition of the crime of genocide under its Article 2. ${ }^{1}$ The ICC Statute also defines Genocide under its Article 6 as exactly as the GC defines. Accordingly, the essence of the crime lies in the attack on specific protected groups of victims. ${ }^{2}$ It can only be committed against national, ethnic, racial or religious groups. ${ }^{3}$

When we look at Ethiopian criminal law, there is a legal definition and constituents elements as to what genocide is under Article 281 of the 1957 Ethiopian Penal Code and Article 269 of the 2004 of FDRE Criminal Code. Here under, the law includes political groups as a target of genocidal act. The inclusion of political groups under Ethiopian criminal law makes the definition of genocide and scope of possible victims wider than the definition of genocide stated under international criminal law. ${ }^{4}$ Sadly, there is no definition of the term used to designate the political groups under the Ethiopian criminal law. This paper has analyzed whether the inclusion of political groups as a target of genocidal act under Ethiopian criminal law is compatible with international criminal law.

\subsection{Objective of the Study}

The paper has the following objective:

$>$ To analysis the legal definition and scope of the crime of genocide provided under Ethiopian Criminal Law in light of GC and ICC Statute.

\subsection{Research Question}

The paper is conducted to answer the following major question:

$>$ Do the legal definition and scope of the crime of genocide provided under Ethiopian criminal law similar with that of the GC and ICC Statute?

\subsection{Methodology}

This research is conducted based on doctrinal legal research methodology. In this research methodology, author was primarily used and applied to examining the legal definition and scope of the crime of genocide in Ethiopian criminal law in light of ICC Statute and GC and it is largely a library work using variety of data sources including relevant national and international laws, cases, books, articles, journals, and other relevant academic literatures has been analyzed.

\section{Literature Review}

\section{General Legal Framework of Genocide}

\subsection{The Legal Definition and Scope of the Crime of Genocide under International Criminal Law}

Genocide, as GA Resolution 96(1) declared, "is a denial of the right of existence of entire human groups, as homicide is the denial of the right to live of individual human beings." ${ }^{5}$ It is a crime simultaneously directed against individual victims, the group to which they belong, and human diversity. ${ }^{6}$

The solid definition of genocide is contained in Article II of the GC, which is adopted verbatim in the statutes of the ad hoc Tribunals and of the ICC. It is any of the following acts committed with the intent to destroy; in whole or in part, a national, ethnical, racial or religious group, as such:

a) Killing members of the group;

b) Causing serious bodily or mental harm to members of the groups;

c) Deliberately inflicting on the group conditions of life calculated to bring about its physical destruction in whole or in part;

d) Imposing measures intended to prevent births within the group;

e) Forcibly transferring children of the group to another group.?

However, clarifying the legal definition of the crime of genocide, Article II and III of the GC were reproduced in a verbatim form in the statutes of ICC and tribunals, such as the ad hoc tribunals for the former ICTY ${ }^{8}$ and

\footnotetext{
Convention for the Prevention and Punishment of the Crime of Genocide, approved and proposed for signature, ratification or accession by the UN General Assembly Resolution 260 A (III) 9 December 1948,78 UNTS 227( hereinafter, GC).

2 Fletcher, G.P. (2002). "Romantics at War: Glory and Guilt in the Age of Terrorism" (Princeton: Princeton University Press), p. 66.

3 Lingaas, C. (2015). "Elephant in the Rome: The Uneasy Task of Defining 'Racial' in International Criminal Law" 15 International Criminal Law Review 485.

GC, Supra note 9, Art 2

Robert C et al., (2007a) . "An Introduction to International Criminal Law and Procedure”, $1^{\text {st }}$ Ed. (Cambridge University Press), p. 165.

Robert C et al., (2010b) . "An Introduction to International Criminal Law and Procedure", $2^{\text {st }}$ Ed. (Cambridge University Press), p. 203.

GC, Supra note 9, Art 2.

Updated Statute of the ICTY, S/Res/827(1993) of 25May 1993, Art 4.
} 
ICTR, ${ }^{1}$ or the ICC. ${ }^{2}$

Broadly speaking, the crime of genocide is comprised of material elements (actus reus) and mental elements (mens rea) which can be divided into: ${ }^{3}$

$>$ The common physical element: victims must belong to a particular national, ethnical, racial or religious groups;

$>$ An additional contextual element with regard to the ICC: the conduct took place in the context of a manifest pattern of similar conduct directed against that group or was conduct that could itself effect the group's destruction;

$>$ The common mental element: Specific intent of the crime of genocide. The perpetrator intended to destroy, in whole or in part, the national, ethnical, racial or religious group, as such;

$>$ The physical (actus reus) ) and mental elements (mens rea) required for each specific or so-called underlying offence.

Even though the definition of genocide, as set down in the international criminal law, has subsequently been reproduced in essentially the same form in Statutes of the ICC and tribunals, its interpretation is still highly contested and has been the subject of much debate. ${ }^{4}$

\subsection{The Legal Definition and Scope of the Crime of Genocide in the Ethiopian Criminal Law}

Ethiopia is the first country to ratify the $1948 \mathrm{GC}^{5}$ After ratifying, it has covered the crime of genocide under Article 281 of the 1957 Penal Code of the Empire of Ethiopia.

Article 281 of the Penal Code defines genocide as international actions meant:

"to destroy, in whole or in part, a national, ethnic, racial, religious, or political group, whether in time of war or peace, in the form of (1) killings, bodily harm or serious injury, (2) measures to prevent the propagation or continued survival of a group, or (3) compulsory movement or dispersion of people, or placing them in living conditions meant to result in their death or disappearance." 6

The title of Article 281 of the Penal Code appears to treat genocide and crimes against humanity as a single offence. ${ }^{7}$ But when we read the content of the Article, it is more or less similar with the definition of genocide under international criminal law.

According to this provision, for a crime of genocide to have been committed, it is necessary to prove that one of acts listed under Article 281(a)(b)(c)of the Code be committed, that the particular act be committed against a specifically targeted group, it being a national, ethnical, racial, religious or political groups and that the act was committed with the specific intent to destroy "in whole or in part."

However, Article 281 of the Penal Code was later repealed in 2004 by the new Criminal Code of FDRE. ${ }^{8}$ According to this Article, genocide means:

" to destroy, in whole or in part, a nation, nationality, ethnical, racial, national, colour (emphases added), religious or political group(emphases added), organizes, orders or engages in time of war or in time of peace: (a) killing, bodily harm or serious injury to the physical or mental health of members of the group, in any way whatsoever or causing them to disappear; or (b) measures to prevent the propagation or continued survival of its members or their progeny; or (c)the compulsory movement or dispersion of peoples or children or their placing under living conditions calculated to result in their death or disappearance."

With the exception of adding "colour" to the list of protected group, "causing members of the group to disappear" to the list of underlying offences and shortening the default punishment to rigorous imprisonment of five to twenty five years and adding life imprisonment to the punishment of more serious cases, it largely retained the elements listed above. ${ }^{9}$ Unlike its 1957 counterpart, it does not mention crimes against humanity. ${ }^{10}$

In conclusion, the inclusion of "color" and "political groups" under Ethiopian Criminal law makes the definition of the crime of genocide and scope of possible victims wider than the definition of the crime of genocide stated under GC and ICC Statute. ${ }^{11}$

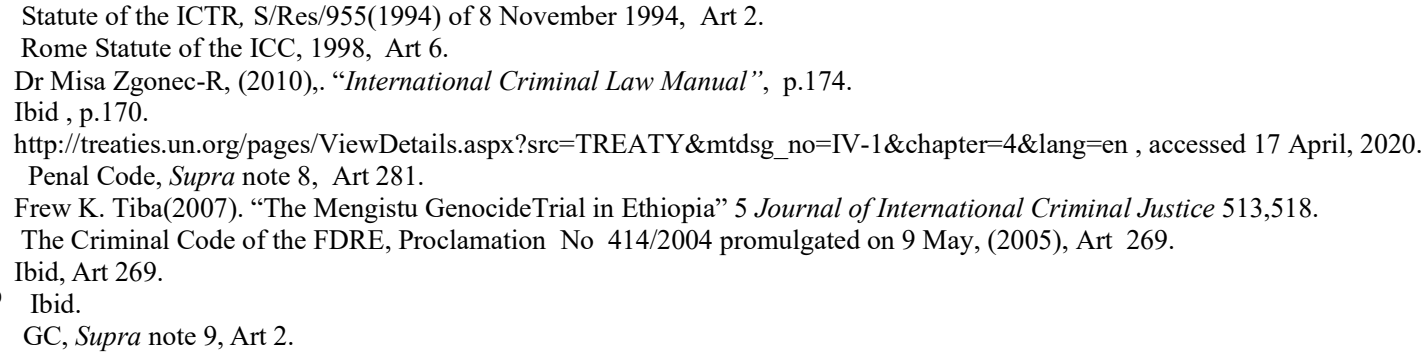




\section{Results and Discussion}

As pointed out above, unlike the Ethiopian criminal law, political group is not a protected group under GC and ICC Statute. To put differently, other groups, such as political groups, are not recognized as protected groups per se under international criminal law. ${ }^{1}$ Thus, extermination based on political opinion is not covered. ${ }^{2}$ Indeed, there is no accepted definition of what political group constitute. Since it is believed that political groups, as "mobile" groups that one joins through individual voluntary commitment, ${ }^{3}$ were beyond the scope of protection of the GC, there were no attempts to define what it means. The four protected groups in the GC have something in common, stability and permanence, as rightly spelled out by ICTR under Akayesu case. ${ }^{4}$ Hence, a political group has no such stability and permanence.

Accordingly, hereunder, there are two arguments for and against the inclusion of political groups as a target of genocidal act under Ethiopian criminal law among scholars. Those authors against the inclusion of political groups hold the view that:

"the scope of protection is extended also to include political groups, which makes it incompatible with the UN GC. In other words, according to his argument, what is considered as genocidal act under Ethiopian criminal law is not considered as such by other international instruments dealing with genocide, and hence it makes it impossible to be regarded as international crime." 5

In addition, one author also argues, "Ethiopia doesn't seem to owe the duty to prosecute those who have been charged of committing genocide on the basis of the GC." 6

Some other authors in the second view, on the other hand, claim that:

"Ethiopian criminal law, which was enacted to give a wider human rights protection, should not be viewed as if it is in contradiction with the GC. As long as Ethiopia does not enact a law that minimizes the protection of rights afforded by the Convention, the mere fact that Ethiopia is a party to the Convention does not prohibit the government from enacting a law, which provides a wider range of protection than the international criminal law. Usually international instruments provide only minimum standards and it is the duty of the Ethiopian Government to enact laws that assist their implementation." 7

When we come to the Ethiopian practice, there is some charge brought against the perpetrators that was based on the crime of genocide committed against political group. For instances, in the case of the SPO vs. Col. Mengistu Hailemariam et al, ${ }^{8}$ the perpetrators has been strongly object the charge based on the inclusion of political group as a victim of genocide crime. They specifically argue that there is no genocide against a political group; Article 281 of the 1957 Penal Code is contrary to the GC; the charge doesn't specify which political group is targeted, and the group listed in the charge is not registered. The SPO in its part replayed that the Penal Code is not contrary to the GC, since it is left to states whether to include or not of the political group and it is not prohibited to include other group in domestic law. However, the court ruled out the objection based on incompatibility to Article 130 of the 1961 Criminal Procedure Code of Ethiopia. ${ }^{9}$

Hereunder, the court has made a mistake in its ruling. It should have analyzed the legality of perpetrator's objection. Article 130 of the 1961 Criminal Procedure Code of Ethiopia doesn't bar the court to analyze the objection. Article 130(1), specifically, provide, form of the charge to be one ground of objection. Thus, by analyzing the form of the charge brought against the perpetrators, the court should have analyzed whether political group should be included in the protected group or in other words the court should analyzed which law-the GC or the Penal Code-is the appropriate law.

As discussed above, political group as a target of genocidal act has no legal recognition and meaning under international criminal law. I didn't find any were any meaning of the term political group for the purpose of the crime of genocide. Weighing up both sides argument raised above, I believe that, since the genocide law was enacted to criminalize such a heinous act against a group and also international conventions provide only minimum standards, those writers argue for the inclusion of the political group as a target of genocidal act under Ethiopian criminal law is a sound argument. Furthermore, including the political group as a target of genocidal act under

\footnotetext{
1 Shneider, H. (2010). "Political Genocide in Latin America: The Need for Reconsidering the Current Internationally Accepted Definition of Genocide in Light of Spanish and Latin American Jurisprudence" 25 American University International Law Review 314.

Bassiouni, M.C. (2013).“Introduction to International Criminal Law” $2^{\text {nd }}$ Revised Ed. (Leiden: Brill), p.154.

Prosecutor v. Jean-Paul Akayesu Case No ICTR-96-4-T-, Para.511.

Ibid, Para.516.

Haile, D. (2000). " Accountability for the crimes of the Past and the Challenges of Criminal Prosecution;

The Case of Ethiopia" Leuven Law Series 42.

Mehari, M.Redae, (2002). "The Ethiopian Genocide Trial” 1 Ethiopian Law Review 2, p. 54.

SPO vs. Col. Mengistu Hailamariam et al., File No. 1/87, Ethiopian Federal High Court (Unpublished), Ruling on Preliminary Objections, 10 October 1996 cited in Hailegebriel, D. (2003). "Prosecution of Genocide at International and National Courts: A Comparative Analysis of Approaches by ICTY/ICTR and Ethiopia/Rwanda," LL.M Thesis, (at Faculty of Law, University of Mekerere), 31 October, p. 16.

8 SPO vs. Col. Mengistu Hailamariam et al., File No. 1/87, Ethiopian Federal High Court (Unpublished), Ruling on Preliminary Objections, 10 October 1996

9 Criminal Procedure Code of Ethiopia, Imperial Ethiopian Government Proclamation No 185 of 1961.
} 
Ethiopian criminal law may not against the purpose of the genocide law and may also compatible with Ethiopia's international obligation to prosecute the crime of genocide.

\section{Conclusion}

From the results of the discussion, it can be concluded that both under the Penal Code of 1957 and the FDRE Criminal Code of 1996, there is a clear divergence with the international criminal law on the definition and scope of the crime of genocide. Unlike international criminal law, Ethiopian criminal law has included political group as a target of genocidal act. The inclusion of political groups makes the Ethiopian's criminal law definition of genocide and scope of possible victims wider than the definition of the crime of genocide under international criminal law. However, such inclusion of political group should not be point of confusion as it gives a wider range of human rights protection than international criminal law.

\section{Reference}

\section{$>$ Books}

+ Dr Misa Zgonec-R (2010).“International Criminal Law Manual.”

* Fletcher, G.P. (2002). "Romantics at War: Glory and Guilt in the Age of Terrorism" (Princeton: Princeton University Press).

* Bassiouni, M.C. (2013). "Introduction to International Criminal Law" 2nd Revised Ed. (Leiden: Brill).

+ Quigley, John B. (2006). "The Genocide Convention: An International Law Analysis” (Aldershot, England: Ashgate Pub).

* Robert, C et al., (2007a). “An Introduction to International Criminal Law and Procedure”, $1^{\text {st }}$ (Ed. Cambridge University Press).

* Robert, C et al., (2010b). “An Introduction to International Criminal Law and Procedure”, $2^{\text {st }}$ Ed. (Cambridge University Press).

\section{$>$ Articles and Thesis}

* Lingaas, C. (2015). "Elephant in the Rome: The Uneasy Task of Defining 'Racial' in International Criminal Law" 15 International Criminal Law Review 485.

* Haile, D. (2000). "Accountability for the crimes of the Past and the Challenges of Criminal Prosecution; The Case of Ethiopia" Leuven Law Series 42

* Hailegebriel, D. (2003). "Prosecution of Genocide at International and National Courts: A Comparative Analysis of Approaches by ICTY/ICTR and Ethiopia/Rwanda," Unpublished LL.M Thesis, (at Faculty of Law , University of Mekerere), 31 October.

\# Frew K. Tiba(2007). "The Mengistu Genocide Trial in Ethiopia" 5 Journal of International Criminal Justice $513,518$.

* Shneider, H. (2010). "Political Genocide in Latin America: The Need for Reconsidering the Current Internationally Accepted Definition of Genocide in Light of Spanish and Latin American Jurisprudence" 25 American University International Law Review 314.

* Jorgensen, (2001). "The Definition of Genocide: Joining the Dots in Light of the Recent Practice" International Criminal Law Review 1, no. 3-4: 285-313.

* Mehari, M.Redae, (2002). "The Ethiopian Genocide Trial” 1 Ethiopian Law Review 2.

\section{$>$ Case laws}

Prosecutor v. Jean-Paul Akayesu Case No ICTR-96-4-T-, Para.511.

* SPO vs. Col. Mengistu Hailamariam et al., File No. 1/87, Ethiopian Federal High Court (Unpublished), Ruling on Preliminary Objections, 10 October 1996.

\section{$>$ Legislations \\ * International}

* Convention for the Prevention and Punishment of the Crime of Genocide, approved and proposed for signature, ratification or accession by the UN General Assembly Resolution 260 A (III) 9 December 1948,78 UNTS 227.

* Statute of the ICTR, S/Res/955(1994) of 8 November 1994.

* Updated Statute of the ICTY, S/Res/827(1993) of 25May 1993

* Rome Statute of the ICC, 1998.

\section{* National}

* Constitution of the Federal Democratic Government of Ethiopia, Proclamation No 1/1995.

* Criminal Procedure Code of Ethiopia, Imperial Ethiopian Government Proclamation No 185 of 1961.

* The Penal Code of the Empire of Ethiopia, Proclamation No. 158/1957, promulgated on 23 July 1957.

* The Criminal Code of the FDRE, Proclamation No 414/2004 promulgated on 9 May, (2005).

\section{$>$ Other Sources}

* http://treaties.un.org/pages/ViewDetails.aspx?src=TREATY\&mtdsg_no=IV1\&chapter=4\&lang=en, accessed 17 April, 2020. 
ICC-ASP $/ 1 / 3$

* U.N.Doc. E/CN.4/Sub.2/416, 4 July 1973.

* U.N. Doc. E/CN.4/Sub.2/1985/6,2 July 1985. 